2 Research Square

\section{Modulation of Plant Functional Traits Under Essential Plant Nutrients During Seasonal Regime in Natural Forests of Garhwal Himalayas}

Amit kumar ( $\square$ amitudu@gmail.com )

Forest Research Institute Dehradun https://orcid.org/0000-0001-7001-3243

\section{Parmanand Kumar}

Forest Research Institute Dehradun

Hukum Singh

Forest Research Institute Dehradun

Narendra Kumar

Forest Research Institute Dehradun

\section{Research Article}

Keywords: Seasonal climate, Physiological traits, macro-micro nutrients, ecosystem services, CO2 assimilation.

Posted Date: February 12th, 2021

DOI: https://doi.org/10.21203/rs.3.rs-212129/v1

License: (ㄷ) (i) This work is licensed under a Creative Commons Attribution 4.0 International License. Read Full License 


\section{Abstract}

Aim: We estimated that how seasonality in conjunction with key climatic variables affects morphological and physiological plant functional traits (PFTs) and soil essential (micro and macro) nutrients in oak, pine, and mixed forests.

Method: The different PFTs were tested using several laboratory methods and also using the portable photosynthesis system Li-COR 6400 XT, Lincoln NE, USA. Likewise, some chemical traits and soil nutrients were analysed by using CHNS analyser.

Results: In this study, physiological traits such as $\mathrm{CO}_{2}$ assimilation rate, stomatal conductance and transpiration rate were found to be significantly higher in the rainy season followed by summer and winter seasons. Among the different forest land uses, physiological traits and resource use efficiency have been significantly higher in oak forest (OF) compared to the mixed forest (MF) and pine forest (PF). Likewise, the concentration of macro-micro nutrients was also recorded higher during the rainy season. The concentration of macro-micro nutrients was higher in OF than in MF and PF in different forest land uses.

Conclusion: Changes in PFTs ultimately affect the ecosystem services imparted by the different forests. Such changes lead to the local adaptation of these forests through the interaction between PFTs and soil nutrients.

\section{Introduction}

Nutrients are indispensable for plants and alteration of nutrient composition adversely affects the physiological and metabolic functioning of plant systems. The deficiency of essential nutrients causes stressful plant conditions, leading to several changes in the plant system including morphological and physiological changes, alternation of metabolic pathways and also shows some disorders in plants such as accumulation of anthocyanin, chloroplast disintegration and loss of chlorophyll (Fathat et al. 2016). Besides, some micronutrients such as manganese (Mn), zinc $(\mathrm{Zn})$, copper $(\mathrm{Cu})$ and iron (Fe) also play a key role in plant physiological functioning and under deficient conditions they limit the synthesis of many enzymes in the plant system that further adversely affect plant metabolism and physiological functioning (Terauchi et al. 2010).

The difference in seasonality like doughtiness (summer), Wetness (rainy) and transition phase in between autumn and spring have a significant effect on morphological and physiological traits such as photosynthesis, stomatal activity and transpiration. Besides that these modified changes in seasonality and plant physiological traits also affect the carbon allocation (above and below ground), plant nutrient absorption and other related features of soil and plant (Kassem et al. 2008). For instance, litterfall is caused in a particular season which decomposes in optimum climatic conditions and contributes various nutrients to the soil in the form of organic compounds.

There is little information on the status of macro and micro-nutrients and their critical levels in forest soils. The physiological traits are responsible for regulating the metabolic activities of the plant system which ultimately affects plant growth and development. These metabolic processes are regulated by the nutrient uptake capacity of the plant which is associated with the amount and distribution of nutrients in the soil (Farhat et al. 2016; Pandey et al. 2017). There is an urgent need to establish a physiologically based critical approach for the diagnosis of nutrients in different parts of the plant, their connection with productivity and to ensure optimum plant functioning. The diagnosis of plant mineral deficiencies by visual symptoms and biochemical techniques are well established (Heckman, 2007), physiological techniques can be a new nutritional diagnostic method if in-situ physiological trait measurement is performed, so that data may be used to estimate and improve productivity. Globally, most mineral nutritionists only work on agricultural crops, not on forestry crops (Conn and Gilliham, 2010). Most of the research is also under refined conditions and does not include the relationship between functional traits of plants and macro-micro nutrients of the soil.

As a result, most of the forests face the problem of low fertility in most parts of the world, their nutritional status and physiological functioning are still unknown, particularly about micronutrients. Difficulty in the measurement of these traits is a significant gap in information on the physiological functioning of forest crops. Forestry crops are very tall, it is very difficult and laborious to measure physiological traits on a standing tree, and this is the key factor that causes the scarcity of the knowledge available for these traits. The relationship between the effectiveness of nutrient usage and physiological characteristics needs to be explored to enhance nutrient use efficiency. A limited study has been reported on the inter-relationship between physiological traits and essential nutrients (Micro and Macronutrients). With this background, we conducted this study with the following objectives (1) to assess the plant functional traits and in different forest during seasonal regimes.

and (2) to evaluate influence of macro-micro nutrients on PFTs during seasonal regimes. We proposed two hypotheses in these two objectives: 1) PFTs will in highly influenced during the seasonal regimes. 2) macro-micro nutrients will strongly stimulate the PFTs in specific seasonal regimes.

\section{Materials And Methods}

\section{Study Site}

The study was carried out in the Kempty watershed of Garhwal Himalaya, India from 2018-2019. The Kempty watershed is situated between $30^{\circ} 28.01-30^{\circ} 28.54^{\prime} \mathrm{N}, 78^{\circ} 1.50-78^{\circ} 2.30^{\prime} \mathrm{E}$, with an average elevation of $1662 \mathrm{~m}$ and an average slope of $5.5 \%$. The watershed is located in the middle part of the Indian Himalayas with an area of 870 ha. The selected forests come under the Himalayan temperate forest. The watershed is comprised 
of two types of forests i.e.Quercus leucotrichophora and Pinus roxburghii forest. Despite this, the forest consists of some other scattered tree species i.e. Quercus leucotrichophora A. Camus ex Bahadur, Quercus floribunda Lindl. ex A. Camus, Pinus roxburghii Sarg., Pinus wallichianai Jackson, Daphniphyllum himalayense Benth., Toona serrate M.Roem., Acer oblongum Wall. ex DC, Pyrus pashia Buch. \& Ham., Cornus macrophylla Wall. and Myrica esculenta Buch.-Ham. Thus, in the present study, we focused on Quercus leucotrichophora forest (OF) and Pinus roxburghii forest (PF) and mixed forest (MF).

\section{Climate and soil}

The climate of the watershed varies from subtropical to temperate, annual precipitation ranges from $850 \mathrm{~mm}$ to $2200 \mathrm{~mm}$ with mean annual precipitation of $1250 \mathrm{~mm}$. The snowfall in winters is a common characteristic of the area. The mean annual maximum air temperature in this watershed varied between 25.12 to $26.82 \varangle \mathrm{C}$, and the mean annual minimum temperature fluctuated between 7.15 to $10.25 \otimes \mathrm{C}$. However, the mean annual air temperature varied between 16.26 to $18.02 \llbracket \mathrm{C}$. Annual precipitations in the watershed ranged from $664.50 \mathrm{~mm}$ to $1370.80 \mathrm{~mm}$ and mean annual relative humidity varied from 55.60 to $75.15 \%$. The texture of the soil is loamy clay, with moderate prone to erosion. Soil is slightly acidic and moderate in nutrients. Mean annual soil moisture varied from $15.15 \%$ to $37.46 \%$.

\section{Field sampling}

Samples were collected by using stratified random sampling at seasonal basis i.e. Rainy, Winter and Summer. According to the structure of the watershed, we stratified the entire watershed into three strata i.e.Q. leucotricophora forests (OF), P. roxburghii forests (PF) and mixed forest (MF). We set total of $20(10 \times 10 \mathrm{~m})$ quadrates in each stratum, however, to collect the leaf samples, 3 trees were selected from 10 (10×10m) quadrates. The samples were collected from bottom, middle and upper capnoy of the tree then ten leaf samples were taken for the analysis of leaf traits. Ten leaf samples were collected from a tree but total 300 (10 leaves $\times 3$ trees $\times 10$ qadrates $=300)$ leaf samples were taken from $10(10 \times 10 \mathrm{~m})$ quadrates in each stratum. The leaf area was measured by using Imagej software. For the analysis of leaf nitrogen concentration (LNC), leaf phosphorus concentration (LPC) and leaf carbon concentration (LCC), the fresh leaf was collected from each sampling points of each stratum. The collected samples were airdried and then oven-dried to make powder for further analysis. LNC, LPC and LCC were measured by using standard protocol for PFTs (PerezHarguindeguy et al. 2013). For the determination of total $P$ in the leaf, the samples were digested using tri acid $\left(\mathrm{HNO}_{3}, \mathrm{HClO}_{4}\right.$ and $\mathrm{H}_{2} \mathrm{SO}_{4}$ in $10: 4: 1$ ratio) then the stock solution was prepared from the digested samples and total $\mathrm{P}$ was analyzed by using the method (Lu, 2000). The total nitrogen and carbon concentration in leaf samples were analyzed by using the CHNS analyzer (Pansuet al., 2001).

\section{Physiological traits measurement}

The physiological traits were measured in a natural condition (intact leaf to the canopy) with the help of a ladder at the seasonal interval (Rainy, winter and summer), three healthy trees were selected and their canopy was stratified into three layer i.e. bottom, middle and upper canopy then eight observations were taken from each layer of canopy of all three (total 30 trees were selected in each stratum) selected trees in each stratum. The total $24 \times 30=720$ observations were taken from each stratum. The physiological traits were measured in fully expanded leaves using an infrared gas analyzer (IRGA) (portable photosynthesis system Li-COR 6400 XT, Lincoln NE, USA instrument) The following physiological traits were directly measured delta $\mathrm{CO}_{2}$ and delta $\mathrm{H}_{2} \mathrm{O}$, leaf temperature, light intensity in the chamber and gas flux; while the following were indirectly measured, based on the algorithms, by the software of system; internal $\mathrm{CO}_{2}$ concentration $\left(\mathrm{Ci}-\mu \mathrm{mol} \mathrm{CO}_{2} \mathrm{~m}^{-2} \mathrm{~s}^{-1}\right)$, transpiration $\left(\mathrm{E}-\mathrm{mmol} \mathrm{H}_{2} \mathrm{O} \mathrm{m} \mathbb{\Xi}^{2} \mathrm{~s} \nabla^{1}\right)$, stomatal conductance (Gs- mol $\mathrm{H}_{2} \mathrm{O} \mathrm{m}^{2} \mathrm{~s} \nabla^{1}$ ) and $\mathrm{CO}_{2}$ assimilation rate $\left(\mathrm{A}-\mu \mathrm{mol} \mathrm{CO} \mathrm{Cm}^{-2} \mathrm{~s}^{-1}\right)$, water use efficiency $\left(\right.$ WUE; $\left.\mathrm{A} / \mathrm{E}-\mu \mathrm{mol} \mathrm{CO}_{2} \mathrm{~mol}^{-1} \mathrm{H}_{2} \mathrm{O}\right)$, instantaneous carboxylation efficiency (CE; A/Ci), instantaneous mesophyll efficiency (ME; A/Gs-), physiological nitrogen use efficiency (NUE; A/N concentration in leaf sample) and physiological phosphorus use efficiency (PUE; A/P concentration in leaf sample). For the measurement of all these parameters, the canopy of selected tree species was stratified into three strata i.e. lower, middle and upper part of the canopy from bottom to top. Then each stratum is further divided into four directions. A total of twelve (three strata and four directions) measurements were taken from a tree. The flat-topped bifurcated aluminum ladder was used to reach all the strata and directions for the measurement of all parameters (Singh et al., 2020).

\section{Macro and micronutrient analysis}

Soil samples (0-30 cm soil depth) were collected from each 40 (10×10m) quadrates from each stratum then 10 quadrates composited to make one replication (total 4 replications $\times 3$ forests $=12$ samples were taken). The collected samples were air-dried and sieved and then different macro-micro nutrients were analyzed. The total $\mathrm{N}$ and $\mathrm{S}$ in soil was estimated by using the CHNS apparatus (Pansuet al.2001). The standard technique for preparing samples into small tin capsules, in the form of tiny pellets was followed. For this, about 15 mg of soil which was finely ground and passed through a $0.2 \mathrm{~mm}$ sieve was taken and placed into the tin capsules. The open end of the capsule was sealed carefully with the help of a pair of forceps and then the sealed capsules were placed in the sample distributor of the CHNS apparatus. Those samples ran with the help of a software

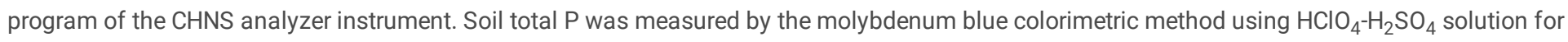
digestion.

For micronutrient $1.0 \mathrm{~g}$ of soil sample was weighed into a $120 \mathrm{ml}$ Teflon PFA microwave digestion vessel and $10 \mathrm{ml}$ of concentrated $\mathrm{HNO}_{3}$ was added (EPA Method 3051, USEPA, 1986). Then samples were capped and weighted to determine possible acid loss during digestion. The samples then were 
digested in a CEM 2000 Microwave digester at 100 pounds per square inch (PSI) for 5.5 min (CEM Corporation, Matthews, NC). Samples were then filtered through Whatman 42 Filters and transferred to $100 \mathrm{ml}$ volumetric flasks. Samples with weight loss of greater than $10 \%$ were re-digested. The final samples were kept in the refrigerator at $4{ }^{\circ} \mathrm{C}$ until the analysis of different micronutrients. After that, the concentration of different micronutrients like (Mg), manganese (Mn), zinc ( $\mathrm{Zn})$, copper (Cu), and iron (Fe) were analyzed using flame atomic absorption spectroscopy (FAAS).

\section{Statistical Analysis}

The difference of all PFTs parameters and macro-micro nutrients were assessed by two-way analysis of variance (ANOVA). Comparison among the PFTs and macro-micro nutrients in all seasons under all forest land uses were made with Duncan's multiple range test at the significant difference $(p<0.05)$. Principal component analysis (PCA) was analyzed between PFTs and macro-micro nutrients for all land uses using R studio.

\section{Results}

\section{Change in physiological plant functional traits}

The present study showed that plant functional traits in different forest types were highly influenced by seasonal variation. Among them rate of $\mathrm{CO}_{2}$ assimilation $\left(A-\mu \mathrm{mol} \mathrm{CO} \mathrm{m}^{-2} \mathrm{~s}^{-1}\right)$ was one of the trait which directly or indirectly affected by the seasonal variations and recorded significantly $(\mathrm{p}<0.05)$ higher in the rainy season (11.93) follwed by summer (9.41) and winter (4.45) (Table 1). Besides that, the rate of $\mathrm{CO}_{2}$ assimilation in forest land use types was recorded higher (Figure 1a) in OF (9.38) follwed by MF (8.50) and at par with PF (7.92). Similar trends was also recorded in case

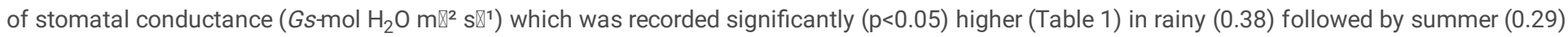
and winter (0.18) seasons. However, among the different forest land uses the highest Gs (Figure 1b) was recorded in OF (0.31) followed by MF (0.28) and PF (0.26). The interaction between season and forest land-use types on stomatal conductance was found to be significant ( $p<0.0001)$. Likewise, transpiration rate $\left(E-m m o l ~ \mathrm{H}_{2} \mathrm{O} \mathbb{m}^{2} \mathrm{~s} \otimes^{1}\right)$ was significantly $(\mathrm{p}<0.05)$ higher (Table 1$)$ in rainy $(9.56)$ while lower in summer $(7.08)$ and winter season (1.22). Irrespective of forest landuses (Figure 1c), OF had the highest (6.82) transpiration rate then MF (5.94) and PF (5.10). The interaction between season and forest land-use types on $\mathrm{E}$ was found to be significant $(\mathrm{p}<0.001)$. However, intercellular $\mathrm{CO}_{2}\left(\mathrm{Ci}_{-}-\mu \mathrm{mol} \mathrm{m}^{-2}\right)$ was observed significantly ( $p>0.05)$ higher (Table 1) in winter (322.92) and lower in autumn (295.70) whereas during summer it was at par (319.53). Notewithstanding this, in forest land uses types the Ci (Figure 1d) was increased in MF (320.17) and decreased in MF (312.91) and OF (305.07).

\section{Change in morpho-biochemical plant traits}

Leaf area was recorded higher (Table 1) during winter $\left(14.80 \mathrm{~cm}^{2}\right)$ whereas lower during rainy season which was at par in summer (14.05 $\left.\mathrm{cm}{ }^{2}\right)$ season. Among the different forest land use types the highest (Figure 2a) leaf area was observed in OF $\left(26.73 \mathrm{~cm}^{2}\right)$ followed by $\mathrm{MF}\left(13.52 \mathrm{~cm}{ }^{2}\right)$ and PF (1.72 $\left.\mathrm{cm}^{2}\right)$. Specific leaf area (SLA) was also found significantly higher in winter followed by rainy and winter season (Table 1). However, in case

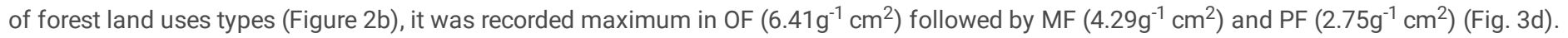
While leaf nitrogen concentration (LNC) was followed the trend, summer > rainy > winter season (Table 1). In case of different forest land uses types (Figure 2c), it was found higher in OF followed by MF and PF. Similar trends was also recorded in case of leaf phosphorous concentration (LPC) and leaf carbon content (LCC) i.e. summer>rainy>winter (Table 1). Also, in case of different forest land use types the trends was OF>MF>PF (Figure 2d\&e).

\section{Change resource use efficiency}

Water use efficiency is inversely proportional to $\mathrm{CO}_{2}$ assimilation rate and transpiration . Our results showed that WUE was significantly ( $\mathrm{p}<0.05$ ) highest (Table 2) during winter (4.0) while lowest during summer (1.40). However, under different forest land-use types, it was significantly higher in PF than that of MF and OF (Figure 3a). Similarly Carboxylation efficiency (CE) is directly proportional to $\mathrm{CO}_{2}$ assimilation rate and stomatal conductance, recorded significantly $(p<0.05)$ higher in rainy $(0.04)$ followed by summer $(0.03)$ and winter $(0.01)$ season $($ Table 2$)$. However, among the different forest land uses, it was higher (Fig. 3b) in OF (0.03) and lower in PF (0.02) which was at par with MF (0.03). The interaction between season and forest land-use types on CE was found to be significant $(p<0.001)$. Likewise, mesophyll efficiency was recorded significantly ( $<<0.05)$ higher (Table 2) in winter (1826.9) and lower in summer (1107.2) and autumn (773.6) seasons. Under different forest land uses types it was recorded higher (Fig. 3c) in PF (1373.3) follwed by MF (1218.8) and OF (1115.6). The interaction between season and forest land-use types on ME was found to be significant $(p<0.0001)$. Nitrogen use efficiency (NUE) followed the similar trends i.e. rainy $(9.23)>$ summer $(6.50)>$ winter $(3.67)$ season $($ Table 2). Among the forest land-use types, NUE was recorded higher (Figure 3d) in OF (6.87) and lower in PF (6.06). In present study phosphorus use efficiency (PUE) also followed the similarly trend as NUE i.e. rainy (114.32)> summer (76.16)> winter (35.54) season (Table 2). However, in the forest land-use types, PUE was recorded maximum (Figure 3e) under MF (78.75) than PF (70.50) and OF (76.76).

\section{Change in macro and micronutrient}

Macronutrients and micronutrients are also directly and indirectly affected by the various seasons and the forest types. Macronutrients i.e. total $\mathrm{N}$ under different season was observed highest during summer and lowest during winter and rainy season (Table 3). In case of different forest land uses types, significantly higher total nitrogen content was recorded in OF followed by MF and PF (Figure 4a). Total P was recorded higher in winter followed by summer and winter season (Table 3). For forest land use types, similar trends have been recorded as for total N i.e. OF>MF>PF (Figure 
4b). The concentration micro-nutrients i.e. Mg was highest in rainy and lowest in winter season (Table 3). While, among the forest land uses the concentration of Mg was increased OF>MF>PF (Figure 5a). Zn concentration was also highest in rainy and lowest was recorded in winter season (Table 3). In case of different forest types the trend of $\mathrm{Zn}$ and Fe concentration was OF>MF>PF (Figure 5b\&c). The concentration of Mn and Cu was increased in rainy >winter>summer (Table 3). Likewise in different forest types the Mn and Cu concentration was higher in OF followed by MF and PF (Figure 5d\&e).

\section{Relationship between plant functional traits and macro-micro nutrients}

The PCA analysis between PFTs and macro-micro nutrients (Fig. 6) showed that forest land-use types are separated in a 2-dimensional ordination diagram by species-level PFTs, and displayed the correlation between PFTs and macro-micro nutrients in each season. Plant functional traits and macro-micro nutrients differed among the seasons as revealed by PCA. The first PCA axis in Fig 8, illustrating 65.6 percent of differences in PFTs and macro-micro nutrients in different seasons. The axis showed that A is passively correlated with another trait i.e.Gs, E, CE, NUE, PAU, LA, SLA, LNC and LCC while negatively correlated with $\mathrm{Ci}$, WUE, ME, SLA, and LPC. Likewise, A is positively correlated with macro-micro nutrients like Mg, Fe, Cu, Mn, Zn and $\mathrm{N}$ while negatively correlated to $\mathrm{P}$ concentration. $\mathrm{Gs}$ is also positively correlated to $\mathrm{Mg}, \mathrm{Fe}, \mathrm{Cu}, \mathrm{Mn}, \mathrm{Zn}$ and $\mathrm{N}$ and negatively correlated to $\mathrm{P}$ concentration. the Same trend was followed in case of transpiration. However, $\mathrm{Ci}$ is negatively correlated to the $\mathrm{Mg}, \mathrm{Fe}, \mathrm{Cu}, \mathrm{Mn}, \mathrm{Zn}$ and $\mathrm{N}$ while positively correlated to $\mathrm{P}$ concentration. The same trend was observed in the case of WUE and ME. CE, NUE and PUE are also positively correlated to $\mathrm{Mg}, \mathrm{Fe}, \mathrm{Cu}, \mathrm{Mn}, \mathrm{Zn}$ and $\mathrm{N}$ and negatively correlated to P concentration. WUE and ME are positively correlated to SLA and LPC while negatively correlated to LA, LNC and LCC. CE and NUE are positively correlated to LA, LNC and LCC while negatively correlated to the SLA and LPC. PUE is positively correlated to LNC and LCC and negatively correlated to the LA, SLA and LPC.

\section{Discussion}

\section{Change in plant functional traits}

Plant functional trait decides the performance of the plant in the forest ecosystem and these traits are highly influenced by the seasonal variation at the species level. These variations alter the metabolic activity of the plant system which leads to suppress the growth and productivity of plants and ultimately affects the ecosystem services governed by the plant community. The rate of $\mathrm{CO}_{2}$ assimilation (photosynthesis) as per the result was recorded higher in the rainy season followed by autumn in all forest land uses. It might be due to the transition phase from summer to the rainy season in which the $\mathrm{CO}_{2}$ assimilation rate was higher than another season. Hence, the growth and productivity also increase which ultimately leads to carbon stabilization in plants and soil systems (Wang et al. 2008). Similarly, stomatal conductance also recorded significantly higher in the rainy season which might be due to abundant water in the soil and high light intensity during the rainy season which enhances the rate of photosynthesis. Moreover, water transportation through xylem during this season was high, due to this it exerts turgor pressure on the stomatal guard cell resulting in the opening of stomata thereby leading to a higher rate of transpiration and carbon assimilation in the plant system (Wang et al. 2008). The rainy season distresses the plant metabolism resulting in increased Rubisco activity and the rate of electron transport in the plant system thus increasing all physiological characteristics of a plant in this season (Hrstka et al. 2012). However, these traits were declined in summer, and winter season in all forest land uses which might be due to the limited water availability. Generally, water and temperature play a key role in determining the growth and productivity of the plant by inhibiting the important enzyme i.e. Rubisco which limits the cycle of carbon assimilation in plants and thus decreases the rate of photosynthesis (Weis et al. 1988; Epron et al. 1992). Similarly, the rate of mesophyll efficiency in the cell during the rainy season is higher due to higher photosynthesis rates and relative quantity yield of PSII at steady-state photosynthesis (Nakagawa et al. 1997).

\section{Change in resource use efficiency}

In the present study, it was very interesting to note that water use efficiency (WUE) and mesophyll efficiency (ME) increased significantly during the winter season compared to the summer and rainy seasons in all forest land uses. Nonetheless, due to increased transpiration and decreased intercellular $\mathrm{CO}_{2}(\mathrm{Cl})$, the rainy and summer seasons showed increased stomatal conductance, typically increased stomatal conductance forces to minimize WUE and ME. The reason for increased WUE and ME might be attributed to plants exposed to winter season fixes more carbon molecule through assimilation and investment of water molecule per fixed carbon molecule is less, ultimately improving WUE and ME (Cowan and Farquhar 1977). Owing to increased $\mathrm{CO}_{2}$ accumulation in the sub-stomatal cavity, the winter season causes a stomatal closer induction and decreases partial $\mathrm{CO}_{2}$ pressure in the leaf. This $\mathrm{CO}_{2}$ dependent amplification of stomatal response may enhance WUE and ME at the leaf as well as canopy level (Long et al. 2004). The findings for WUE, ME a CE in the present study are following the observations of other researchers worldwide Hao et al. 2016; Singh et al. 2017; Purcell et al. 2018 and Singh et al. 2018). Higher stomatal conductivity and increased intercellular $\mathrm{CO}_{2}$ concentration of mesophyll cells may stimulate photosynthesis with higher yields (Hao et al. 2016). However, CE showed the inverse trend to the WUE and ME. The higher CE was observed during rainy season over summer and winter season. It could be attributed to increased water capacity and nutrient absorption through the plant roots encouraging increased yield and carboxylation efficiency (Palta et al. 2007).

Furthermore, nitrogen and phosphorus are the key elements in soil involved in an integral part of functional and structural protein, amino acid, chlorophyll, nucleic acid, hormone and other organic molecules and play a pivotal role in the growth and biomass production of tree species. The concentration of nitrogen and phosphorus and its distribution in tree species determines biomass productivity. However, NUE and PUE are directly 


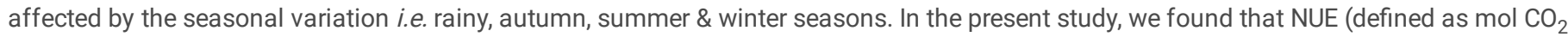
assimilated $\mathrm{g}^{-1}$ leaf $\mathrm{N}$ ) and PUE (defined as $\mathrm{mol} \mathrm{CO}_{2}$ assimilated $\mathrm{g}^{-1}$ leaf $\mathrm{P}$ ) also decreased from rainy season to winter (Rainy>summer>winter) over the study period. This is consistent with other reports on NUE and PUE in drought-affected deciduous tree species (Reich et al. 1995; Abrams et al. 1995). High NUE and PUE during the early rainy season came at the cost of maintaining high water-use efficiency (WUE; $\mathrm{CO}_{2}$ assimilated per mol of $\mathrm{H}_{2} \mathrm{O}$ transpired). The enhanced ability of water and nutrient absorption through the roots of plants is encouraging increased yield and nitrogen and phosphorus use efficiencies (Palta et al. 2007). As water availability decreased later in the season, WUE improved while NUE and PUE decreased. Similarly, decreased NUE and PUE might be due to the rapid nitrogen and phosphorus losses by different processes such as denitrification, ammonia volatilization, leaching and surface runoff which enhances significant environmental problems, for instance, soil acidification, air pollution, water eutrophication as well as suppressing growth and development of plants (Diaz and Rosenberg 2008; Guo et al. 2010).

In the present study, the relative nutrient abundance in the litterfall was in order $\mathrm{C}>\mathrm{N}>\mathrm{P}$, which coincides with studies from various forest ecosystems (Garkoti and Singh 1995). The nutrient inputs were within the range during the study and also reported for many temperate broadleaved forests in central Himalayas (Singh et al. 2009). Significant $(p<0.05)$ variation was recorded in N, P and C concentration of leaves during various seasons. The maximum concentration of all these elements was recorded in the rainy season than summer. Higher concentrations of nutrients in summers may be attributed to increased nutrient re-absorption in summer from senescent tissues. However, the wood litter in the forests has lower concentrations of N, P and K than the leaf litter and shows no significant seasonal variations compared to the leaf litter (Arunachalam et al. 1998).

The present study found that total $\mathrm{N}$ concentrations were significantly higher $(\mathrm{p}<0.05)$ during the rainy over summer season in various forest land uses. Among these, total $\mathrm{N}$ was significantly maximum in OF followed by MF and PF. It might be due to the higher immobilization of soil nutrients by the microbes due to the higher microbial activity decomposition rate of litter on the forest floor is also higher. Another probable reason for the increased concentration of $\mathrm{N}$ in rainy season maybe because of the higher activity of nitrogen-fixing microbes. These nitrogen-fixing bacteria play a key role in mineralization during rainy season and increased the rate of $\mathrm{N}$ mineralization in the soil (Bergeron et al., 2002). The increased concentration of total $\mathrm{N}$ in rainy season reflects the fixation of blue-green algae and released nitrogen through the process of microbial decomposition (Salim et al 2015). The intake of plant nutrients during the summer season is significantly reduced because $\mathrm{N}$-mineralization and nitrification are either immobilized in microbial biomass or stored in the soil as inorganic nitrogen (Singh and Singh, 2006).

\section{Change in macronutrients}

Results of the present study showed that the concentration of total $\mathrm{N}$ was significantly higher in OF during summer season which might be due to more litter accumulation, low soil compaction, least exposer of particulate organic matter to microbial attack and quick oxidation in forest land uses (Wiesmeier et al. 2012; Twongyirwe et al. 2013; Zhang et al. 2013). Stockmann et al. (2013) also showed that the concentration of N was increased from grassland to cropland or from cropland to the forest land uses. In general, PF soils have compact, low litter and residue input, increased exposure of organic particulate matter to microbial attack and rapid oxidation are the factors which reduce $\mathrm{N}$ in PF compared to OF (Karcheggani et al. 2012; Wiesmeier et al. 2012). Yadav et al. ( 2019) also reported that total N was higher in OF and MF compared to PF due to less aggregation and decomposition of litter in PF compared to OF and less soil compaction with less bulk density in OF than PF.

The concentration of total P was significantly $(\mathrm{p}<0.05)$ higher in winter season and minimum in summer season. Among the land use types, it was high in OF followed by MF and minimum in PF. It could be due to the accumulation of more minerals and less rainfall during winter season than summer which leads to less leaching of nutrients from the soil. However, a lower concentration of total $P$ in rainy season might be due to heavy rainfall and soil erosion which results in leaching the majority of $\mathrm{P}$ is leached down. Soils with maximum erosion and leaching are known to have a low concentration of $\mathrm{P}$ in comparison to the soil with minimum erosion and leaching (Ashraf et al. 2012). It has been observed that when the level of $\mathrm{P}$ and organic carbon is high in the soil, the amount of potential seasonal variation of phosphorus values tends to increase (Semwal et al., 2009; Salim et al. 2015). The higher concentration of $P$ in OF is also due to the highest content of organic matter in the OF which has a great potential to supply a sufficient amount of organic phosphate to the plants from the soil (Miller and Donahuer 2001). Gupta and Sharma (2008) also reported that carbon and phosphorus were positively correlated because all these attributes were intimately linked with soil humus.

\section{Change in micronutrients}

Micronutrients are dynamically acquired to plants through their roots, but to optimize the uptake of micronutrients certain conditions are required. The nutrient uptake is greatly influenced by seasonality due to the availability of different temperature and moisture. The results revealed that the highest concentration of micronutrients was recorded in OF during rainy season and lower in PF during summer season which is due to the availability of optimum temperature and moisture content during rainy season than summer. Results of the previous study revealed that low temperature and moisture status tends to decline root growth rate and their metabolism, microbial activity, decomposition of organic matter and reduces the bioavailability of micronutrient (Fahad et al. 2017; Pandey et al. 2017). Moreover, decomposition of organic matter on the forest floor produces some humic substances (humic and fulvic acids) and can chelate micronutrient ions, resulting in increased mobility of micronutrient in soil (Havlin et al. 2013). Some micronutrients exit at low soil concentration and are thus transported by diffusion through soil water to the surface of the roots thereby reducing the movement of ions in dry soil due to enhanced tortuosity of the diffusion path (Barber 1995). During summer, low water availability causes the slowdown of micronutrient mobility, their assimilation and absorption in the root. Few studies also reported that the deficiency of micronutrients is most likely occurring in summer season due to reduced mass flow as well as diffusion to roots (Singh et al. 2016; Rahman et al.

Page 6/13 
2020). Additionally, the reduced movement of micronutrients and their uptake under summer conditions ultimately affects the translocation of micronutrients from root to shoot (Baghour et al. 2002). In another report, it was mentioned that drought and saturated soil conditions restrict the root growth, which ultimately reduces transpiration and would help observe lower uptake of micronutrient by the plants (Rahman et al. 2020). In rainy season, the water-saturated condition of soil has shown that micronutrients are transferred from exchangeable and soluble forms to oxide forms (Zheng and Zhang 2011). To elucidate the impact of soil moisture on micronutrient transformation, the site-specific or in-situ soil moisture regimes should be adequately managed as dry soil conditions may result in a return to similar oxidation states and types. Therefore it is concerning that our findings showed irregular micronutrient distribution across various seasons and forest land uses.

\section{Relationship between plant functional traits and macro-micro nutrients}

The macro-micro nutrient is the essential elements, some of these are most frequently required for the physiological functioning of the plants while some restrict the process. Nitrogen is one of the most prevalent elements its deprivation causes deviations in a vast range of physiological and morphological functioning of the plants (Zhao et al. 2005). The present study revealed that soil $\mathrm{N}$ content is positively correlated with several traits such as photosynthesis, stomatal behavior and transpiration. Nitrogen is indeed a very essential component as it forms a major component of chlorophyll and plays important role in the photosynthesis process (using sunlight, water and $\mathrm{CO}_{2}$ produce photosynthate) (Tang et al. 2019). It is also a major constituent of amino acids which are the building blocks of the protein without these proteins plant cannot survive. Similarly, phosphorus is also an essential element for the health and vigor of plants. It is a dynamic component of ATP (energy unit of the plant), forms during photosynthesis (Thuynsma et al. 2016). Although in our study P is negatively correlated to photosynthesis, stomatal conductance and transpiration because the concentration of $\mathrm{P}$ is higher during winter season and negatively correlated with the physiological traits during rainy season. Magnesium also has a significantly strong association with physiological characteristics. It could be because Mg is the main atom and the building block of the chlorophyll molecule involved in the photosynthesis process. Besides that, it is also responsible for the activation of many enzymes which are very important for protein growth and synthesis(Farhat et al. 2016). In the present study, Iron has also a significant correlation with physiological traits. It is required as a cofactor for protein which is involved in several metabolic processes like photosynthesis and respiration (Terauchi et al. 2010). Similarly, manganese also plays a key role in the physiological functioning of the plant (Alloway 2008). It has relatively low phloem mobility in plants, resulting in deficiency symptoms appear in the younger leaves. It is also observed that copper is also showing a positive connection with the physiological traits and activates several plant enzymes that are involved in lignin synthesis (Yruela 2009). It is also actively involved in photosynthesis and respiration processes and helps to regulate the protein and carbohydrate metabolism in plants. Zn is one the essential micronutrient which is important for the various physiological processes such as photosynthesis, stomatal conductance and transpiration. It is involved in increasing the chlorophyll content, the net rate of photosynthesis, stomatal conductance and rate of transpiration in higher plants, thereby increasing photoassimilates in plant leaves (Sun and Yang 2002; Wei et al. 2005).

\section{Conclusion}

Understanding the functioning of soil and plants during the annual season is more important in the Himalayan ecosystem leading to changes in the functioning of the ecosystem due to climate change. With changing climatic conditions nutrient cycling is severely affected by the alteration of species composition in the Himalayan ecosystem. The findings of the present study revealed that physiological characteristics have been reduced during the winter season and enhancement during the rainy season is not only an outcome of the functioning of the plant leaf but is also controlled by different environmental drivers. Plants and soil ecosystems are also affected by the temporal variability of macro and micronutrients in the soil. Besides, this study specifies all the forest land uses having enormous potential to manage the resources such as nutrient regulation in the Himalayan region during the adverse changing climatic conditions to (i) attain very high rates of nutrient assimilation when sufficient amount of moisture content is available and (ii) retain the ability to increase soil nutrients. Therefore, the present findings revealed that selected forests can regulate the nutrient cycle against the different seasonal variations and could be used to select other forests that have the potential to regulate the nutrient cycle in the Indian Himalayan region.

\section{Declarations}

\section{Conflict of interest:}

The authors declare that they have no conflict of interest.

\section{References}

Ajwa HA, TabatabaiMA(1994). Decomposition of different organic materials in soils.BiolFertil Soils.18: 175-182.

AllowayBJ(2008). Zinc in soils and crop nutrition.

Arunachalam A, Maithani K, Pandey HN, TripathiRS(1998). Leaf litter decomposition and nutrient mineralization patterns in regrowing stands of a humid subtropical forest after tree cutting.Forest Ecology and Management109(1-3): 151-161.

Page $7 / 13$ 
Ashraf M, Bhatt GA, Dar ID, Ali M(2014).Physicochemical characteristics of grassland soils of Yusmarg Hill Resort (Kashmir, India), Eco.Balkanica 4: 31-38.

Baghour M, DA, Moreno G, Villora I, Lopez-Cantarero J, Hernandez N, CastillaRomeroL(2002). Root-zone temperature influences the distribution of Cu and $\mathrm{Zn}$ in potato-plant organs. J.Agri.\& Food Chem 50(1): 140-146. doi: 10.1021/jf010375j.

Barber SA,(1995). Soil nutrient bioavailability: A mechanistic approach. 2nd ed. Hoboken, NJ: John Wiley \& Sons. Singh, U., C. S. Praharaj, S. S. Singh, and N. P. Singh. 2016. Biofortification of Food Crops, New Delhi: Springer India.

Black CA(1982). Methods of soil analysis.Part 2.Chemical and microbiological properties.American Society of Agronomy, Madison.

Diaz RJ, Rosenberg R (2008).Spreading dead zones and consequences for marine ecosystems.Science321: $926-929$.

Epron D, Dreyer E, Breda N(1992). Photosynthesis of oak trees [Quercuspetraea (Matt.) Liebl.] during drought under field conditions: Diurnal course of net $\mathrm{CO}_{2}$ assimilation and photochemical efficiency of photosystem II. Plant, Cell \& Environment 15 (7): 809-820.

Fahad SA, Bajwa A, Nazir U, Anjum SA, Farooq A, Zohaib A, Sadia S, NasimW, Adkins S, Saud S(2017). Crop production under drought and heat stress: Plant responses and management options. Frontiers in Plant Science 8:1147.doi: 10.3389/fpls.2017.01147.

Farhat N, Elkhouni A, Zorrig W, Smaoui A, Abdelly C, Rabhi M(2016).Effects of magnesium deficiency on photosynthesis and carbohydrate partitioning. Actaphysiologiaeplantarum 38(6): 145.

Garkoti SC, Singh SP (1995). Forest floor mass, litter fall and nutrient return in central Himalayan high altitude forests. Vegetation 120 : $33-48$.

Guo JH, Liu XJ, Zhang Y(20100. Significant acidification in major Chinese croplands.Science327: 1008-1010. DOI: 10.1126/science.1182570.

Gupta MK, Sharma SD(2008). Effect of tree plantation on soil properties, profile morphology and productivity index I. Poplar in Uttrakhand. Ann. For. 16: (2), 209-224.

Havlin JL, Tisdale SL, Nelson WL, BeatonJD. 2013. Soil fertility and fertilizers: An introduction to nutrient management. 8th ed. Upper Saddle River, NJ: Prentice Hall.

Hrstka M, Urban O, BabakL(2012).Seasonal changes of Rubisco content and activity in Fagus sylvatica and Piceaabies affected by elevated $\mathrm{CO}_{2}$ concentration. Chemical Papers. 66:(9): 836-841.

IPCC.(2007). The physical science basis. Contribution of working group I to the fourth assessment report of the Intergovernmental Panel on Climate Change: Cambridge University Press, Cambridge, UK and NY, USA, 996-2007.

Kassem II, Joshi P, Sigler V, Heckathorn S, Wang Q(2008). Effect of elevated $\mathrm{CO}_{2}$ and drought on soil microbial community associated with Andropogongerardii. J. Integr Plant Biol50: 1406-1415.

Kohler J, Knapp BA, Waldhuber S, Caravaca F, Roldan A, Insam H,(2010).Effects of elevated $\mathrm{CO}_{2}$, water stress, and inoculation with Glomus intraradices or Psedomonasmendocina on lettuce dry mater and rhizosphere microbial and functional diversity under growth chamber conditions.J Soil Sediment.10: 1585-1597.

Lu,RK(20000. Analysis Methods of Soil Agricultural Chemistry, Chinese Agricultural Science and Technology Press, Beijing, 2000.

Miller RW, DonahuerRL(2001). Soils in our Environment”.Seventhedition.Prentice Hall, Inc. Upper Saddle River, New Jersy.

Nakagawa H, Horiem T, Kim HY, Ohnishi H, Homma K(1997). Rice responses to elevated $\mathrm{CO}_{2}$ concentrations and high temperatures: J. Agriculture Meteorology52: 797-800.

Palta JA,Fillery IR, RebetzkeGJ(2007). Restricted-tillering wheat does not lead to greater investment in roots and early nitrogen uptake. Field Crops Research104: 52-59.

Pandey PV, Irulappan MV, Bagavathiannan M Kumar S(2017). Impact of combined abiotic and biotic stresses on plant growth and avenues for crop improvement by exploiting physio-morphological traits. Frontiers in Plant Science 8:537. doi: 10.3389/fpls.2017.00537.

Paudel S, Vetaas OR(2014).Effects of topography and land use on woody plant species composition and beta diversity in an arid Trans-Himalayan landscape, Nepal.J.Mountain Science 11: 1112-1122.

Perez-Harguindeguy N, Diaz S, Garnier E, Lavorel S, Poorter H, Jaureguiberry P, Bret-Harte MS, Cornwell WK, Craine JM, Gurvich DE, Urcelay C, Veneklaas EJ, Reich PB, Poorter L, Wright IBJ, Ray P, Enrico L, Pausas JG, de Vos AC, Buchmann N, Funes G, Quétier F, Hodgson JG, Thompson K, 
Morgan HD, TerSteege H, Van der Heijden MGA, Sack L, Blonder B, Poschlod P, Vaieretti MV, Conti G, Staver AC, Aquino S, Cornelissen JHC(20130. New handbook for standardized measurement of plant functional traits worldwide.Aust. J. Botany64(8): 715-716.

Reich PB, Ellsworth DS, UhIC(1995). Leaf carbon and nutrient assimilation and conservation in species of differing successional status in an oligotrophic Amazonian forest.Functional Ecology 1, 65-76.

Salim M, Kumar P, Gupta MK, Kumar S(2015). Seasonal variation in some chemical characteristics of the soil under different land uses of JhilmilJheel wetland, Haridwar-Uttrakhand, India. International Journal of Scientific and Research Publications 5(10): 1-9.

Semwal DP, Uniyal PL, bahuguna YM, Bhatt AB(2009). Soil nutrient storage under different forest types in a part of central Himalayas, India. Ann. Forest 17(1): 43-52.

Singh AN, Singh JS(2006). Experiments on ecological restoration coalmine spoil using native trees in a dry tropical environment, India: a synthesis. New Forest 45:25-39.

Singh KP, Ghoshal N, Singh S(2009). Soil carbon dioxide flux, carbon sequestration and crop productivity in a tropical dryland agroecosystem: Influence of organic inputs of varying resource quality. Applied Soil Ecology42(3): 243-53.

Singh SP, ThadaniR(2015). Complexities and Controversies in Himalayan Research: A Call for Collaboration and Rigor for Better Data. Mountain Research and Development.35(4): 401-409.

Stockmann U, Mark A, Adams JW, Crawford DJ, Field N, Henakaarchchi MJ, BudimanM(2013). The knowns, known unknowns and unknowns of sequestration of soil organic carbon. Agriculture, Ecosystems \& Environment 164: 80-99.

Sun GF, Yang GS(2002). Research progress of zinc in soil plant system. J. South China Univ. Trop. Agric 8: 22-30.

Tang J, Sun B, ChengR, Shi Z, Luo D, Liu S, Centritto M(2019).Effects of soil nitrogen (N) deficiency on photosynthetic N-use efficiency in N-fixing and non-N-fixing tree seedlings in subtropical China. Scientific reports 9(1): 1-14.

Terauchi AM, Peers G, Kobayashi MC, Niyogi KK, Merchant SS (2010). Trophic status of Chlamydomonasreinhardtii influences the impact of iron deficiency on photosynthesis. Photosynthesis research, 105(1): 39-49.

Thuynsma R, Kleinert A, Kossmann J, Valentine AJ, Hills PN(2016). The effects of limiting phosphate on photosynthesis and growth of Lotus japonicus. South African Journal of Botany. 104: 244-248.

Twongyirwe R, Sheil D, Majaliwa JGM, Ebanyat P, Tenywa MM, van Heist M, Kumar L(2013). Variability of soil organic carbon stocks under different land uses: a study in an afro-montane landscape in southwestern Uganda. Geoderma 193: 282-289.

USEPA.(1986). Test methods for evaluating solid waste. Vol. IA. 3rd ed. EPA/SW-846. Natl. Tech. Inf. Serv., Springfield, VA.

Wang D, Heckathorn SA, Barua D, Joshi P, HamiltonEW, LaCroix JJ (2008). Effects of elevated $\mathrm{CO}_{2}$ on the tolerance of photosynthesis to acute heat stress in C3, C4, and CAM species. Am J Bot. 95:165-176.

Wei X.R, Hao MD, Zhang CX, Wang XG(2005).Effect of soil drought condition of exogenous zinc, manganese on photosynthetic characteristics of summer maize.ActaAgron.Sin. 31: 1101-1104.

Weis EN, Berry JA(1988). Plants and high temperature stress: Sym. Society. Experimental Biology.42: 329-346.

Wong S(1990). Elevated atmospheric partial pressure of $\mathrm{CO}_{2}$ and plant growth.Photosynth Res. 23: 171-180.

Yadav RP, Gupta B, Bhutia PL, Bisht JK, PattanayakA(2019). Biomass and carbon budgeting of land use types along elevation gradient in Central Himalayas. J. Cleaner. Production.211: 1284-1298.

Yruelal(2005). Copper in plants. Brazilian Journal of Plant Physiology. 17(1): 145-156.

Zhao D, Reddy KR, Kakani VG, Reddy VR(2005). Nitrogen deficiency effects on plant growth, leaf photosynthesis, and hyperspectral reflectance properties of sorghum. European journal of agronomy, 22(4): 391-403.

Zheng SA, Zhang MK(2011). Effect of moisture regime on the redistribution of heavy metals in paddy soil. J. Environmental Sciences 23(3):434-43. doi: 10.1016/S1001-0742(10)60428-7.

Zhang N, Guo R, Song P, Guo J, Gao Y(2013). Effects of warming and nitrogen deposition on the coupling mechanism between soil nitrogen and phosphorus in Songnen Meadow Steppe, northeastern China. Soil Biology and Biochemistry. 65: 96-104. 


\section{Tables}

Table 1: Plant functional traits during different seasonal regimes.

\begin{tabular}{|c|c|c|c|c|c|c|c|c|c|}
\hline & $A$ & Gs & $E$ & $\mathrm{Ci}$ & LA & SLA & LNC & LPC & LCC \\
\hline Rainy & $11.93^{a} \pm 0.65$ & $0.38^{a} \pm 0.01$ & $9.56^{a} \pm 0.55$ & $295.70^{b} \pm 5.45$ & $13.12^{c} \pm 1.02$ & $3.69_{ \pm 0}{ }_{ \pm 0} .90$ & $1.29^{b} \pm 0.01$ & $0.11^{c} \pm 0.01$ & $50.39^{a} \pm 0.24$ \\
\hline Winter & $4.45^{c} \pm 0.45$ & $0.18^{c} \pm 0.01$ & $1.22^{c} \pm 0.25$ & $322.92^{a} \pm 3.64$ & $14.80^{a} \pm 0.98$ & $4.97^{a} \pm 1.14$ & $1.21^{b} \pm 0.03$ & $0.13^{a} \pm 0.01$ & $47.77^{b} \pm 0.35$ \\
\hline \multirow[t]{2}{*}{ Summer } & $9.41^{b} \pm 0.37$ & $0.29^{b} \pm 0.01$ & $7.08^{b} \pm 0.87$ & $319.53^{\mathrm{a}} \pm 3.21$ & $14.05^{b} \pm 1.05$ & $4.80^{b} \pm 1.14$ & $1.45^{a} \pm 0.02$ & $0.12^{b} \pm 0.01$ & $50.26^{a} \pm 0.26$ \\
\hline & $\begin{array}{l}F=87.05 \\
p<0.0001\end{array}$ & $\begin{array}{l}F=45.57 \\
p<0.0001\end{array}$ & $\begin{array}{l}F=142.35 \\
p<0.0001\end{array}$ & $\begin{array}{l}F=326.40 \\
p<0.0001\end{array}$ & $\begin{array}{l}F=557.09 \\
p<0.0001\end{array}$ & $\begin{array}{l}F=133.42, \\
p<0.0001\end{array}$ & $\begin{array}{l}F=83.74 \\
p<0.0001\end{array}$ & $\begin{array}{l}\text { F3.62, } \\
p<0.04\end{array}$ & $\begin{array}{l}F=10.57 \\
p<0.004\end{array}$ \\
\hline
\end{tabular}

Table 2: Resource use efficiencies during different seasonal regimes.

\begin{tabular}{|c|c|c|c|c|c|}
\hline & WUE & CE & $\mathrm{ME}$ & NUE & PUE \\
\hline Rainy & $1.25^{b} \pm 0.04$ & $0.04^{\mathrm{a}} \pm 0.001$ & $773.60^{c} \pm 40.30$ & $9.23^{a} \pm 0.50$ & $114.32^{a} \pm 6.59$ \\
\hline Winter & $4.00^{a} \pm 0.66$ & $0.01^{c} \pm 0.001$ & $1826.90^{a} \pm 89.56$ & $3.67^{c} \pm 0.35$ & $35.54^{c_{ \pm}} \pm 4.57$ \\
\hline \multirow[t]{2}{*}{ Summer } & $1.40^{b} \pm 0.17$ & $0.03^{b} \pm 0.001$ & $1107.20^{b} \pm 47.26$ & $6.50^{b} \pm 0.23$ & $76.16^{\mathrm{b}} \pm 4.37$ \\
\hline & $F=11.37, p<0.0001$ & $F=48.32, p<0.0001$ & $F=348.12, p<0.0001$ & $F=86.38, p<0.0001$ & $F=147.54, p<0.000$ \\
\hline
\end{tabular}

Table 3: Macro-micro nutrients concentration during different seasonal regimes.

\begin{tabular}{|c|c|c|c|c|c|c|c|}
\hline & $\mathrm{N}$ & $P$ & $\mathrm{Mg}$ & $\mathrm{Fe}$ & $\mathrm{Cu}$ & $\mathrm{Zn}$ & $\mathrm{Mn}$ \\
\hline Rainy & $783.01^{c} \pm 44.34$ & $122.55^{c} \pm 6.69$ & $69.36^{a} \pm 2.59$ & $41.46^{a} \pm 2.41$ & $14.83^{a} \pm 1.70$ & $68.57^{a} \pm 2.72$ & $55.24^{a} \pm 1.84$ \\
\hline Winter & $1004.08^{b} \pm 50.98$ & $155.11^{a} \pm 5.05$ & $59.46^{b} \pm 2.16$ & $33.00^{b} \pm 1.93$ & $12.49^{b} \pm 1.50$ & $59.62^{b} \pm 1.67$ & $43.42^{b} \pm 1.72$ \\
\hline \multirow[t]{2}{*}{ Summer } & $1104.11^{a} \pm 48.22$ & $144.21^{b} \pm 6.31$ & $48.85^{c} \pm 2.72$ & $29.25^{c} \pm 1.11$ & $10.70^{c} \pm 1.03$ & $47.41^{c} \pm 2.07$ & $35.09^{c} \pm 2.02$ \\
\hline & $\begin{array}{l}F=356.42, \\
p<0.0001\end{array}$ & $\begin{array}{l}F=152.36 \\
p<0.0001\end{array}$ & $\begin{array}{l}F=141.02 \\
p<0.0001\end{array}$ & $\begin{array}{l}F=168.45 \\
p<0.0001\end{array}$ & $\begin{array}{l}F=82.06 \\
p<0.0001\end{array}$ & $\begin{array}{l}F=198.35 \\
p<0.0001\end{array}$ & $\begin{array}{l}F=192.44, \\
p<0.0001\end{array}$ \\
\hline
\end{tabular}

\section{Figures}



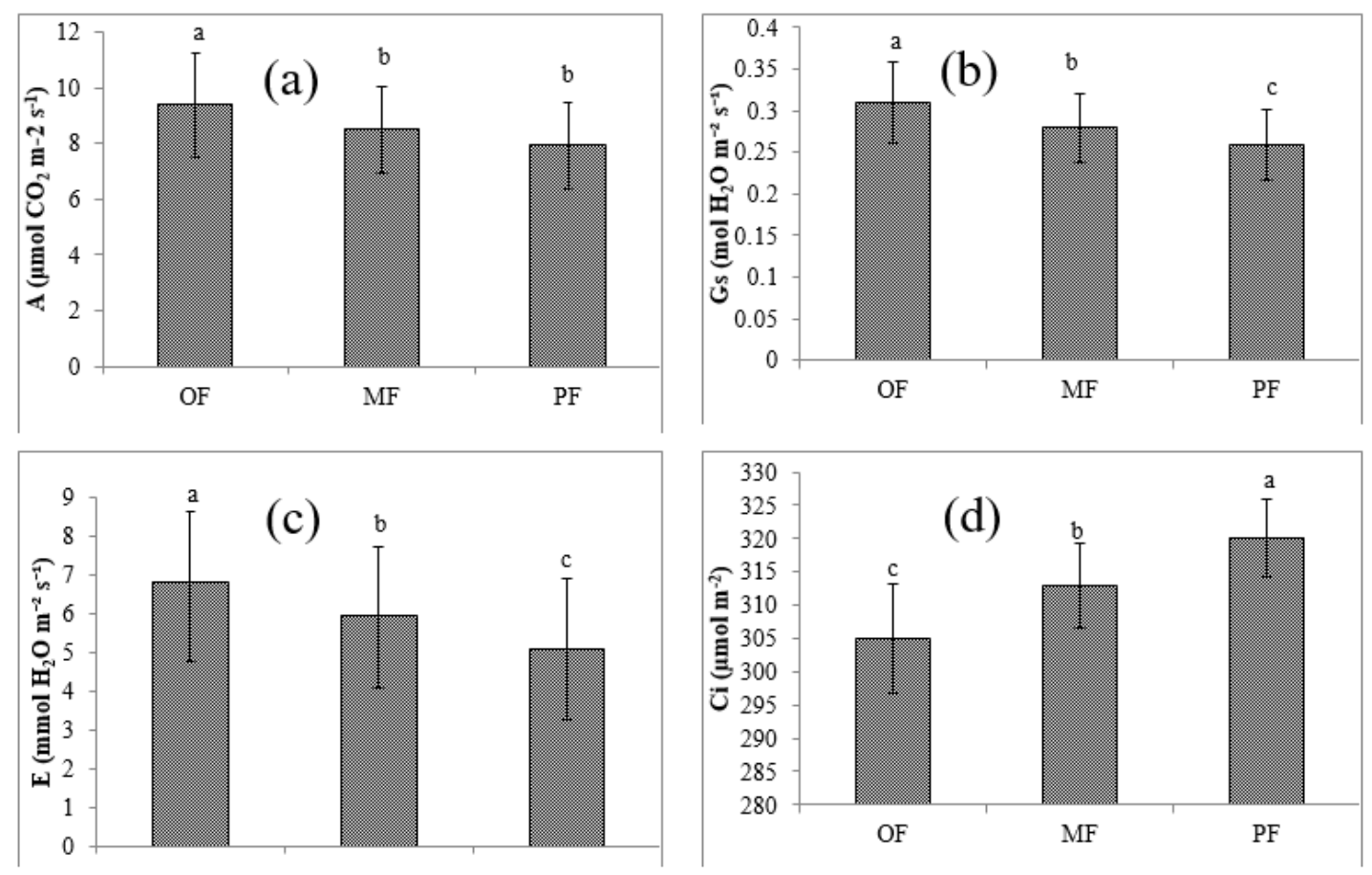

Figure 1

Physiological plant functional traits under different forest land uses.
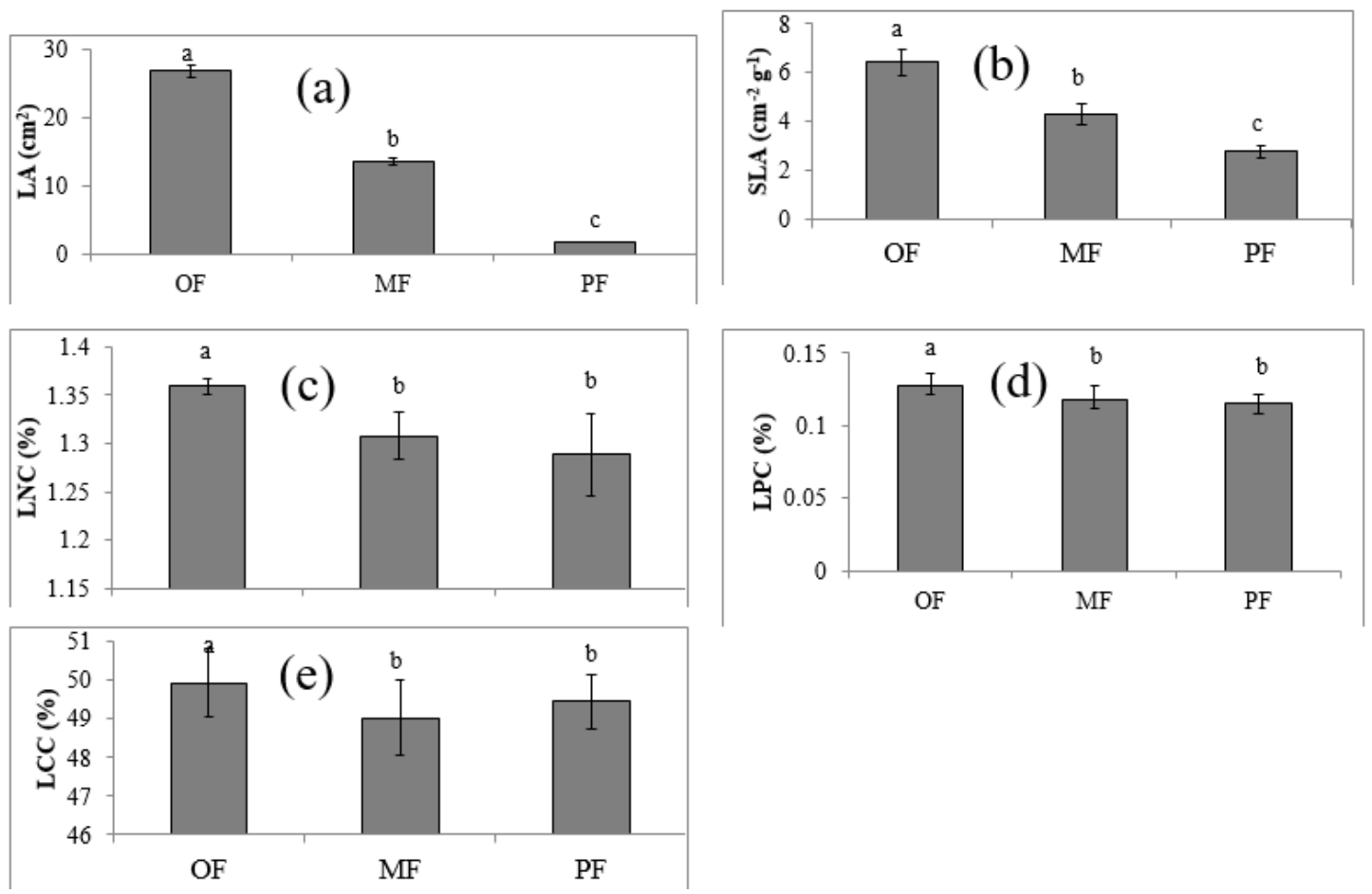

Figure 2

Leaf traits under different forest land uses. 

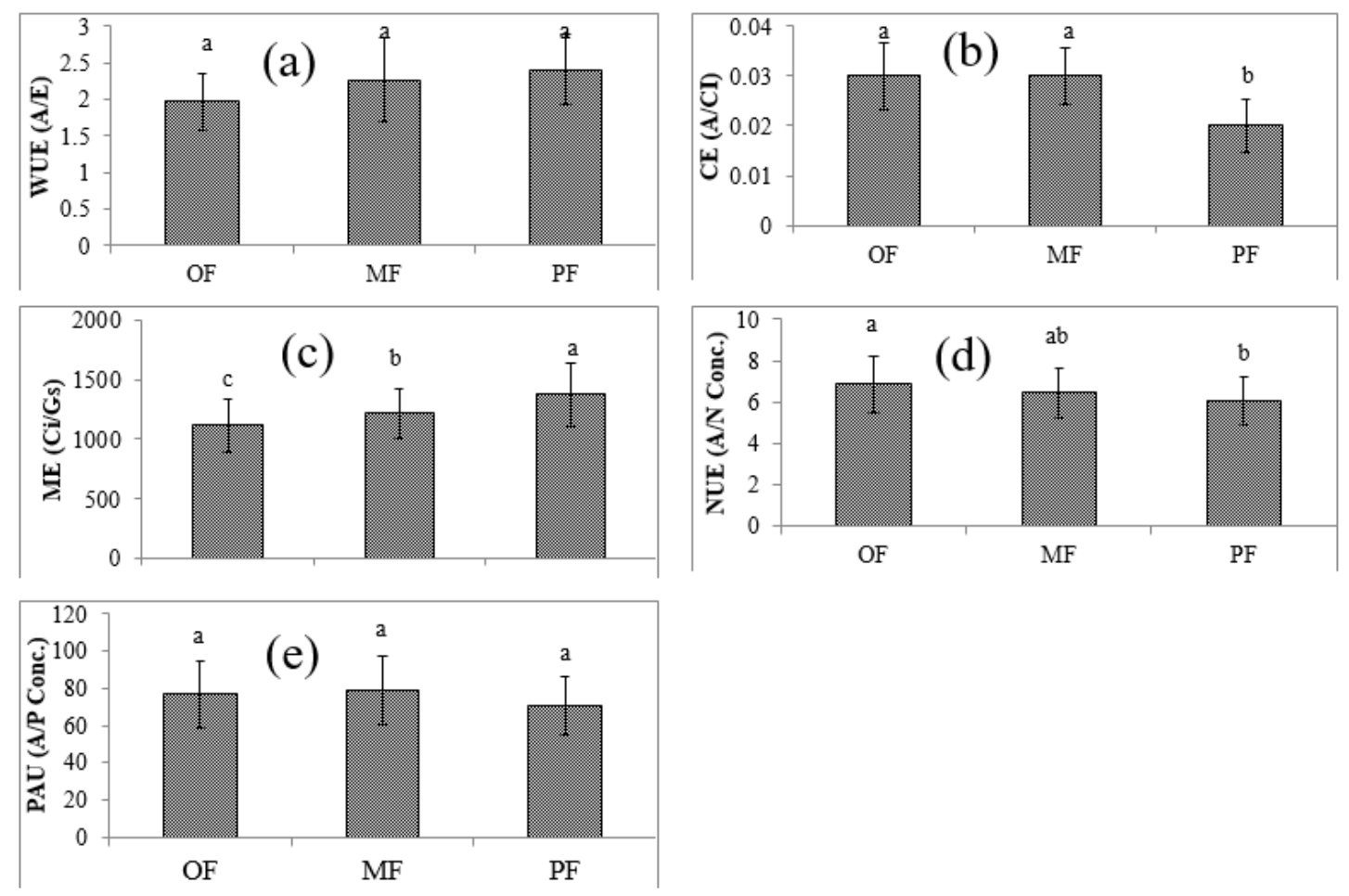

Figure 3

Resource use efficiency under different forest land uses.
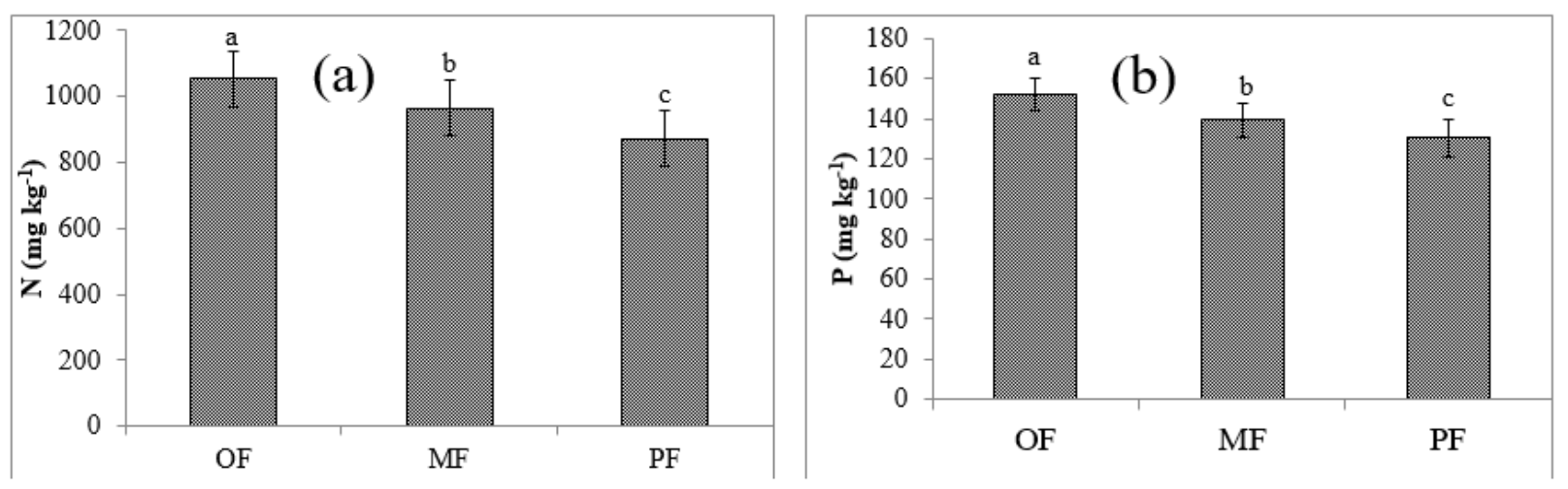

Figure 4

Macro nutrients under different forest land uses. 

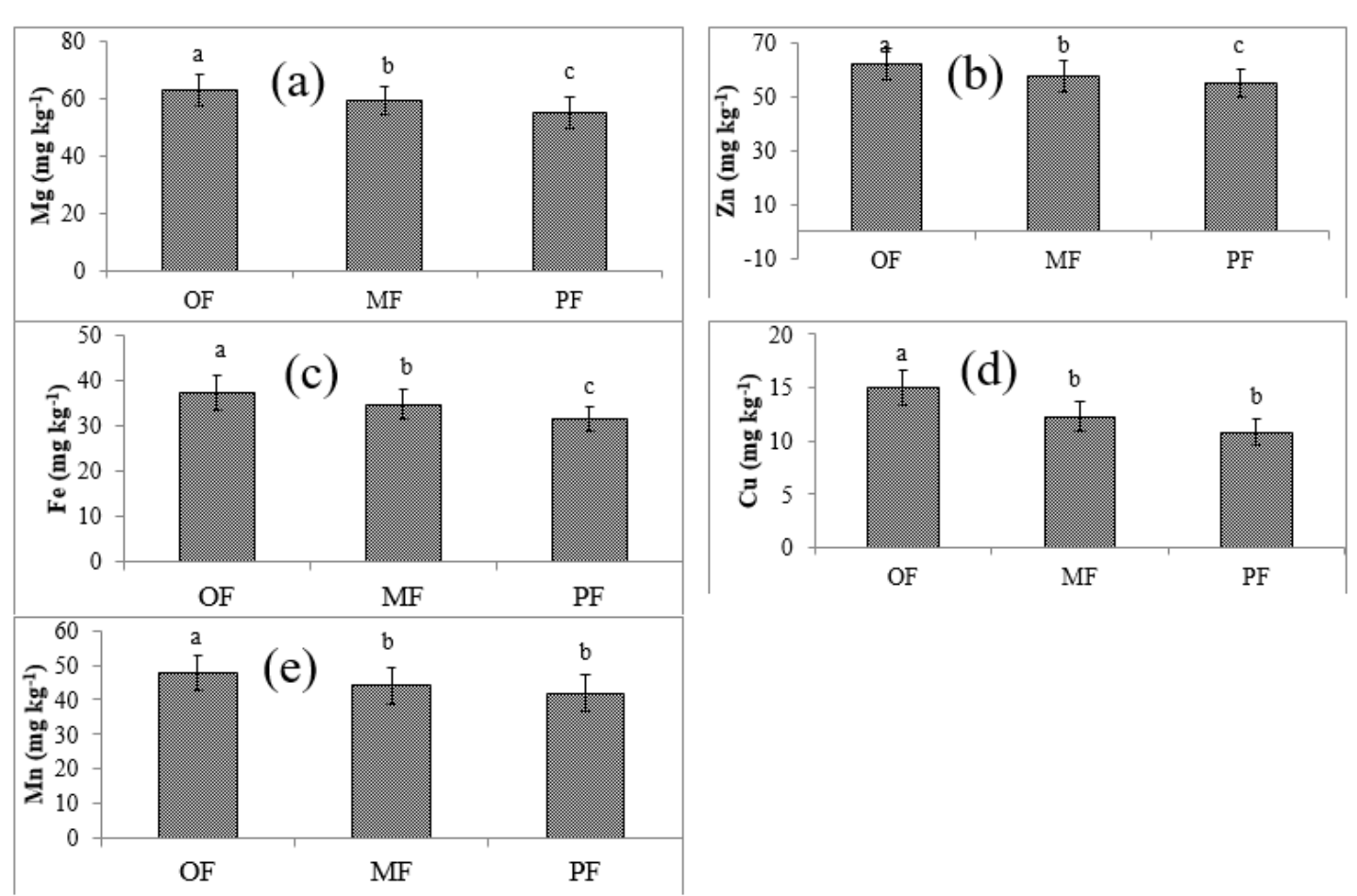

Figure 5

Micro nutrients under different forest land uses.

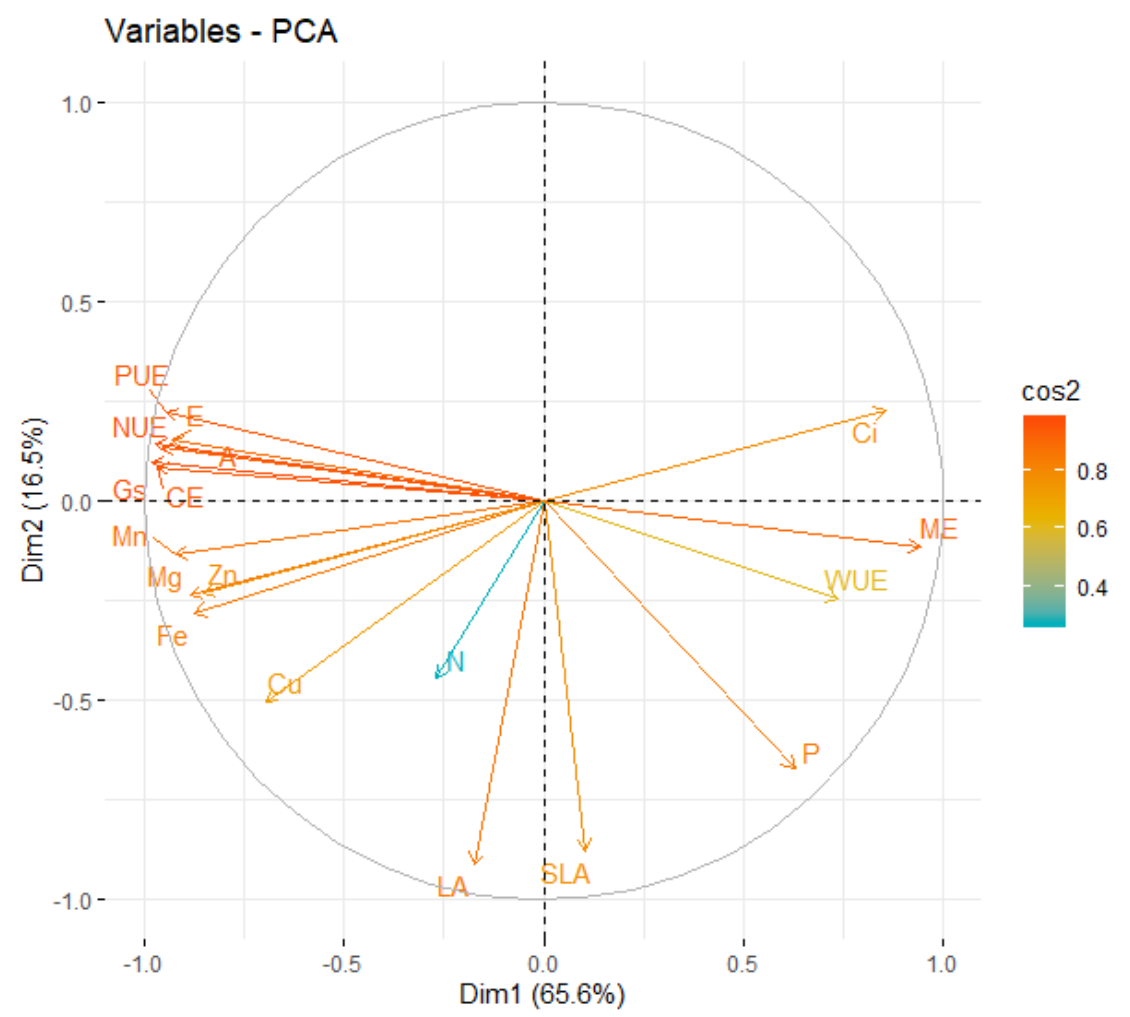

\section{Figure 6}

Principle component analysis between plant functional traits, macro and micro nutrients. 